\title{
IDENTIFICATION OF THE BARRIERS TO BUSINESS IN SLOVAKIA
}

Barriers are the problems with which every company meets. These problems affect companies negatively. The aim of this paper is to identify major barriers in selected industry of the Slovak business environment. To fulfill the aim of the paper, a primary research, based on the methods of querying, analysis, comparison and selection, was conducted. The questionnaire was focused on identifying barriers in the Slovak business environment from the view of advertising agencies operating in the Zilina region. We can conclude that respondents can be divided into three groups: companies whose business is affected by the barriers, companies whose business is partly influenced by barriers, companies whose business is not affected by the barriers. We can deduce, according to respondents, that the main barrier to business is represented by the work of public administrative bodies.

Keywords: Advertising agencies, business environment, internal barriers, external barriers.

\section{Introduction}

The current period is characterized by many changes. Constantly creating new products, new markets bring new opportunities but also threats. Each company tries to cope with the competitive environment and deliver the best possible competitive position. For success in business areas is not enough to accurately know business' environment. Achieved business results are diverse in market environment. Business success is contingent upon the choice and implementation of strategies for maintaining and growth of competitiveness. An appropriately chosen strategy leads to the proper direction of the company, or, at the time of corporate crisis to save the company itself [1].

Every company meets with a problem which negatively affects its business results. Such problems are referred to as barriers and can be so serious that will require plenty of time and cost to remove them. On the other hand, there are barriers that hardly affect the company. It depends on whether a company is fully prepared to start a business, if it has a capable manager who can advise in such situations or if it is an experienced company. In fact, every company depends on the set of managerial decisions and actions by which network management determines in advance what should be accomplished and how it should be achieved [2]. Therefore, it is necessary to report every important activity of the company. This is compounded by the fact that companies face the increased demand for information about them [3]. It is important to realize that companies can exist in various forms, which is a feature that has impact on company's effort to create something new or to improve something what already exists. Also, actions of every company are externally assessed, which promotes its reputation [4].

The aim of the paper is to identify major barriers in selected industry of the Slovak business environment. The paper consists of four parts. An input to the problem and theoretical definitions of internal and external barriers in the business are included in introduction. Methodology describes paper's creation process and methods used to fulfill the aim of the paper. Results part comprises primary research aimed at identifying major barriers in Slovak advertising industry. The last part - conclusion - evaluates the results of primary research.

\section{Theoretical background}

Since companies are making significant means for acquiring and preserving information, the lack of information certainly isn't one of the most serious problems of present days [5]. The driving forces behind success of a company are not only information and technologies but even broader

\footnotetext{
* Mariana Strenitzerova - Miriam Garbarova

Department of Communications, Faculty of Operation and Economics of Transport and Communications, University of Zilina, Slovakia

E-mail: mariana.strenitzerova@fpedas.uniza.sk
} 
term - innovations [6]. A positive fact is that nowadays, companies are even more successful in overcoming major barriers to innovation [7]. Perfect market does not exist and anyone who wants to start a business must carve out its place in the market. In every country, there are not only barriers to the development of business environment but even efforts to remove them. In accordance with a primary classification, barriers to business are divided into internal barriers and external barriers.

\subsection{Internal barriers to business}

Internal barriers to business are conceptual barriers to company's progress which are represented by the lack of interest, lack of opportunity and/or lack of capacity. These barriers affect issues around perceived risk, competing priorities, internal support and skills [8]. Internal barriers to business are numerous, multi-dimensional, interdependent and are categorized into three clusters [9]:

a) Opportunity cost of investment: When companies consider investing, they compare the expected rates of return with those of alternative investments they could make. Companies may wait and grow into base of the pyramid markets by acquiring small companies that are successful. These circumstances make it difficult for decision-makers to justify the opportunity cost of investing when other investments with higher, more certain rates of return are available.

b) Strategic and operational misalignment: Every company is a matter of procuring, manufacturing, distributing, marketing and selling products and services. Private companies can't be run out of the public affairs department because key functional teams across the company need to be involved, especially to do it at scale. However, some operating structures and processes can't easily be leveraged. Thus, lower expected rates of return and lack of clarity about the relative importance of commercial and social objectives can also cause strategic and operational misalignment.

c) Capability gaps: Companies' capabilities drive their performance. The extent to which capabilities need to be adapted or built from scratch is a critical success factor of every company. "These can include the ability to implement any of the solutions outlined in the annex, from managing informal distribution channels to providing inventory on credit to processing hundreds of thousands of small transactions". It is often possible to acquire the capabilities necessary to bring a company to its success.

\subsection{External barriers to business}

External barriers to business are mainly represented by the threats companies face when entering a new market and which are described in Michael Porter's five forces model. These five barriers are the same threats a company faces when it wants to grow [10]:

a) Threat of new entrants: Profitable markets that yield high returns will attract new companies. This results in many new entrants which eventually will decrease profitability for all companies in the industry. Unless the entry of new companies can be blocked by incumbents, an abnormal profit rate will trend towards zero.

b) Threat of substitutes: The existence of products outside of the realm of the common product boundaries increases the propensity of customers to switch to alternatives.

c) Bargaining power of buyers: The bargaining power of customers is also described as the market of outputs. Customers have the ability to put a company under pressure which also affects the customer's sensitivity to price changes. Companies can take measures to reduce buyer power, such as implementing a loyalty program.

d) Bargaining power of suppliers: The bargaining power of suppliers is also described as the market of inputs. Suppliers of raw materials, components, labor and services to a company can be a source of power over another company when there are few substitutes.

e) Industry rivalry: For most industries, the intensity of competitive rivalry is the major determinant of the competitiveness of the industry.

Any of these threats could affect the growth of a small, as well as a large company [11]. Besides external barriers described in Michael Porter's five forces model, other external barriers may come from low demand of the product or service from customers, difficult access to raw materials, late payments of bills by business customers, government interference, public procurement rules and regulations-related difficulties in exporting the product to foreign countries [12]. External barriers most frequently occur in export [13]. The most effective tools to overcome such barriers are knowledge and information [14]. Another possibility is to overcome external barriers by funding from the public sector which is linked not only to the non-profit sector but even to the private sector [15].

\section{Methodology}

The aim of the paper is to identify major barriers in selected industry of the Slovak business environment. The main motive for the selection of the paper's topic were researches conducted by various authors who have dealt 
with barriers to business in the conditions of Latin America [16 and 17]. To fulfill the aim of the paper, it was necessary to understand terms related to barriers to business. We are inclined to a primary classification which identifies internal barriers and external barriers to business.

Another step is performing a primary research, based on the methods of querying, analysis, comparison and selection. Respondents were represented by companies operating in the advertising industry. To evaluate statistical indicators, the formula for small core files and unknown distribution, critical value, dispersion, variability of core group of respondents ( $p$ $=0.5$ ) and maximum allowable margin of errors $\langle \pm 10 \% ; \pm 2 \%\rangle$ were used [18].

Respondents were contacted via e-mail and telephone. The questionnaire, focused on identifying barriers in the Slovak business environment from the view of advertising agencies operating in the Zilina region, consisted of 20 questions. The results of questions related to the aim of this paper are to be presented in the form of text and graphs.

\section{Results}

The Slovak advertising industry consists of two components - media agencies dealing with buying shares of media market and communications market. Communications market covers all agencies focusing on creative advertising, PR agencies and production companies. The industry experienced the biggest boom in the late nineties. It grew annually by $20.00 \%$ between years 2005 and 2008. In 2009, as a result of the economic crisis, a turnover in the market fell by $35.00 \%$ [19].

Business environment in Slovakia is not facing serious problems threatening the existence of companies because the situation is slowly improving due to the new laws and support programs created by the Slovak Government. Although, there are certainly various barriers and the aim of our primary research was to find them. The main source of primary research was the questionnaire focused on identifying barriers in the Slovak business environment from the view of advertising agencies operating in the Zilina region. The questionnaire was composed of questions mapping the possible barriers that companies come into contact with when performing their activities. 50 companies were approached, nevertheless only 34 of them answered. This represents a $68.00 \%$ rate of return. $38.20 \%$ of companies have existed less than five years, $32.40 \%$ of companies have existed from six to ten years and remaining $29.40 \%$ of companies have existed more than 10 years.

When speaking about the impact of the company's position on its results, $55.90 \%$ of companies are unaware of any impact, $38.20 \%$ of companies perceive a positive impact and $5.90 \%$ experience a negative impact. It is striking that $70.60 \%$ of companies have faced some strong barriers to business and only $29.40 \%$ of companies have never faced such barriers.

We assumed that the incomprehensibility of laws represents a major barrier to business in Slovakia. This assumption was partially confirmed, since $58.30 \%$ of companies said that the incomprehensibility of laws has a partial impact on their business, $12.50 \%$ of companies perceive significant impact and $29.20 \%$ do not perceive any impact. This is related to the intensity of the monitoring of changes in the law. Some companies monitor such changes on a monthly basis, other companies monitor such changes on a quarterly, half-yearly or annual basis. There are even companies that do not monitor such changes at all. Summary of replies is depicted in Fig. 1.

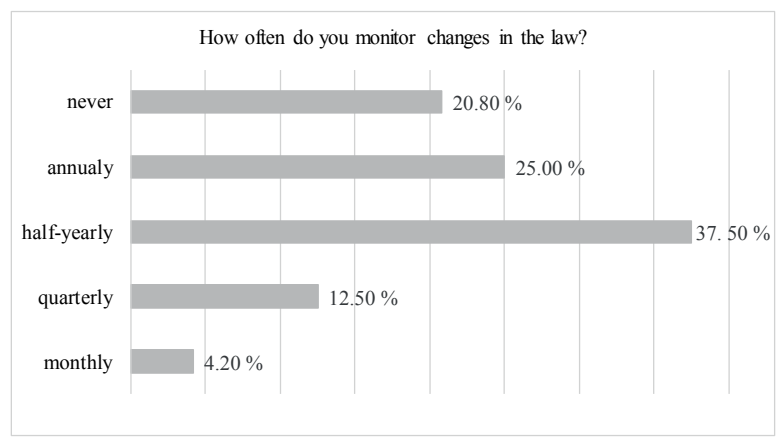

Fig. 1 The intensity of the monitoring of changes in the law (Source: Own research)

We also assumed that the competitive pressure is another major barrier to business. However, it is interesting that some companies $(20.80 \%)$ do not monitor activities of their competitors at all. Fortunately, $29.20 \%$ of companies monitor the activities of their competitors in detail and $50.00 \%$ of companies monitor the activities of their competitors only partially.

Finally, we come to the most important question in which respondents were supposed to identify major barriers to business. Respondents had the possibility to mark several options. Summary of replies is depicted in Fig. 2.

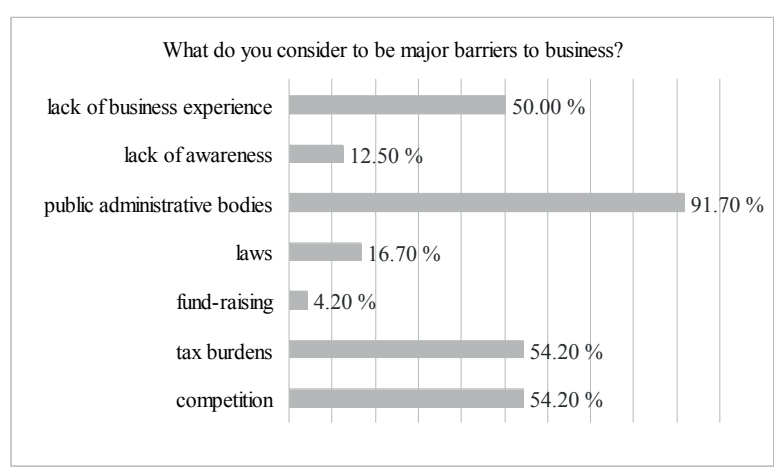

Fig. 2 Major barriers to business identified by respondents (Source: Own research) 
According to respondents, the main barrier to business is represented by the work of public administrative bodies which affects activities of companies because they have to face this barrier every day. This is a problem that company can't influence in any way because the work of public administrative bodies determines general rules which have to be followed.

\section{Conclusion}

When it comes to addressing internal and external barriers companies face, it catalyzes greater and more open dialogue on solutions companies can use to tackle them. However, the bigger barrier, the more difficult solution is required. Even though, the most important is to be able to identify the barriers. The aim of the paper was to identify major barriers in selected industry of the Slovak business environment. To fulfill the aim of the paper, a primary research, based on the methods of querying, analysis, comparison and selection, was conducted. The questionnaire, focused on identifying barriers in the Slovak business environment from the view of advertising agencies operating in the Zilina region, consisted of 20 questions. Respondents were contacted via e-mail and telephone. The questionnaire was composed of questions mapping the possible barriers that companies come into contact with when performing their activities. 50 companies were approached, nevertheless only 34 of them answered. We can conclude that respondents can be divided into three groups: a) companies whose business is affected by the barriers,

b) companies whose business is partly influenced by barriers,

c) companies whose business is not affected by the barriers.

We assumed that the incomprehensibility of laws represents a major barrier to business in Slovakia. This assumption was partially confirmed, since $58.30 \%$ of companies said that the incomprehensibility of laws has a partial impact on their business, $12.50 \%$ of companies perceive significant impact and $29.20 \%$ do not perceive any impact. We also assumed that the competitive pressure is another major barrier to business. However, it is interesting that $20.80 \%$ of companies do not monitor activities of their competitors at all. Fortunately, $29.20 \%$ of companies monitor the activities of their competitors in detail and $50.00 \%$ of companies monitor the activities of their competitors only partially. Finally, these are major barriers to business identified by respondents:

a) public administrative bodies (91.70\%),

b) competition $(54.20 \%)$

c) tax burdens $(54.20 \%)$,

d) lack of business experience $(50.00 \%)$,

e) laws $(16.70 \%)$

f) lack of awareness $(12.50 \%)$,

g) fund-raising $(4.20 \%)$.

The paper provided a very general look at what barriers came to the attention of companies. Since the size of the sample has limited the possibility of generalization of the results, this leads us to future research aimed at the larger sample of companies. Also, it would be interesting to conduct similar research in another industry and to compare the results with our results gained in an advertising industry.

\section{References}

[1] VRABlOVA, L., GREGOR, M.: Company in Crisis. Communications - Scientific Letters of the University of Zilina, No. 4, 2011, 78-81. ISSN 1335-4205.

[2] HITTMAR, S., JANKAL, R.: Strategic Management of Networks. Management of Network Organizations: Theoretical Problems and the Dilemmas in Practice, 2015, 5-21, Cham : Springer International Publishing.

[3] VARTIAK, L.: CSR Reporting of Companies on a Global Scale. Procedia Economics and Finance, 39, 2016, 176-183. ISSN 2212-5671.

[4] VARTIAK, L.: Importance of Reputation in the Assessment of Corporate Social Responsibility, Proc. of CBU intern. Conference Innovations in Science and Education, 2015, 82-88, Prague. ISBN 978-80-88042-00-6.

[5] JANKALOVA, M.: Business Calculations (in Slovak), Zilinska univerzita, 2014.

[6] STOFKOVA, J. et al.: Business Management, Bratislava : DOLIS, 2015.

[7] EUCHNER, J.: Declining Barriers to Innovation, Research-Technology Management, 58(6), 2015, 10-11.

[8] BCTA (2010). BARRIERS TO PROGRESS: A Review of Challenges and Solutions to Inclusive Business Growth. Retrieved August 17, 2016, from http://www. businesscalltoaction.org/wp-content/uploads/2010/11/Barriers-to-Inclusive-BusinessFinal-11.12.2010-LR.pdf.

[9] WBCSD: Scaling up Inclusive Business: Solutions to Overcome Internal Barriers, Geneve : WBCSD, 2013.

[10] PORTER, M. E.: The Five Competitive Forces that Shape Strategy, Harvard Business Review, January 2008, 86-104.

[11] HISRICH, R. D., PETERS, M. P.: Entrepreneurship, Sydney : McGraw-Hill/Irwin, 2002. 
[12] BARTLETT, W., BUKVIC, V.: Barriers to SME Growth in Slovenia, MOST : Economic Policy in Transitional Economies, 11(2), 2001, 177-195.

[13] KAHIYA, E. T., EAN, D. L.: Export Barriers and Business Confidence: A Quasi-Longitudinal Examination. Asia Pacific J. of Marketing and Logistics, 27(2), 2015, 294-323.

[14] MATOS, P., MENESES, R.: The Importance of Knowledge and Information to Overtake Export Barriers: A Case Study of Portuguese SME. Innovation, Entrepreneurship and Sustainable Value Chain in a Dynamic Environment, Proc. of $8^{\text {th }}$ Annual conference of the EuroMed Academy of Business, 1515-1528, 2015, Verona : University of Verona.

[15] RENTKOVA, K., MAJERCAKOVA, D.: Financing and Cooperation between the Public Administration and Non-Profit Sector in the Slovak Republic. ACRN J. of Finance and Risk Perspectives, 2(2), 2013, 60-68.

[16] CAHEN, F. R. et al.: Managerial Perceptions of Barriers to Internationalization: An Examination of Brazil's New Technology-based Firms. J. of Business Research, 69(6), 2016, 1973-1979.

[17] CARDOZA, G. et al.: Barriers and Public Policies Affecting the International Expansion of Latin American SMEs: Evidence from Brazil, Colombia and Peru. J. of Business Research, 69(6), 2016, 2030-2039.

[18] FORET, M., STAVKOVA, J.: Marketing Research: How to Know our Customers (in Czech), Prague : Grada Publishing, 2003.

[19] Neulogy 2013: Report on the State and Potential of the Creative Industry in Slovakia (in Slovak), Bratislava : Neulogy, 2013. 